\title{
A Novel Work on Employee Satisfaction
}

\section{R. Ramamoorthy, Venkat Raman S, Anitha. K}

\begin{abstract}
Agent association implies managing the association between the various laborers in an affiliation. The relationship can be among laborer and the business similarly as between delegates at a comparative level. It is critical that delegates share a sound association with each other at the work place. There are a couple of issues on which an individual can't take decisions alone. Laborers are the critical assets of an affiliation. It is fundamental that the laborers perform together as a total unit and contribute comparably towards the affirmation of a common target. publicizing frameworks and unequivocal to various associations.
\end{abstract}

\section{Keywords: Employee relations, Work behaviour}

\section{INTRODUCTION}

Agent relations imply the relationship shared among the laborers in an affiliation. The agents must approve of each other for a strong circumstance at work. It is the prime commitment of the supervisors and gathering pioneers to debilitate conflicts in the gathering and engage a strong relationship among laborers. [1],[3],[5] Every individual offers a particular relationship with his accomplices at the workplace. The relationship is either warm, not by any means positive or negative or terrible. The relationship can be between any one in the affiliation - between partners, between a laborer and his overwhelming, between two people in the organization, and so on [2],[4],[6]

It is huge that the laborers share a strong relationship with each other to pass on their best shows. An agent must endeavor his level best to adjust with each other and deal to his most perfect degree. One needs to enter his office with a positive temper and should not unnecessarily make issues out of easily overlooked details.

It is of most extraordinary hugeness that laborers continue with each other in a refined way, respect each other and make sense of how to trust in each other. An individual in any case continuing on he is, can't do considers alone. It is essential that all of the agents share an inviting association with each other, see each other's needs and wants and work together to accomplish the destinations and focal points of the affiliation.One of the essential advantages of worker relations is that associations can keep up sound representative worker connections. By standing up to and adequately overseeing working environment strife, businesses limit possibly troublesome conduct. Peace making likewise enables administrators to institute and uphold

Revised Manuscript Received on July 22, 2019.

Mr. R. Ramamoorthy, Department of MBA, Bharath Institute of Higher Education and Research, Chennai, India.

Email: ramamoorthy0071@gmail.com

Venkat Raman S, Department of Civil Engineering, Bharath Institute of Higher Education and Research, Chennai, India.

Email:mailmagik@yahoo.com

Anitha . K, Department of Civil Engineering, Bharath Institute of Higher Education and Research, Chennai, India

Email: anithakrish26@yahoo.co.in formal disciplinary methodology and increment specialist steadfastness. Perceiving and averting work environment issues early additionally enables representatives to concentrate on their expert advancement, and bolster generally speaking authoritative objectives. In progressively level associations, compelling representative relations advances a culture that perceives and considers the interests and prosperity of workers [7], [9], [11]

\section{OBJECTIVES}

- To ascertain the factors influencing employee relations

- To identify the working atmosphere factors which helps in building employee relation.

- To analyse in which organisational hierarchy the employee relationship is better.

\section{RESULTS AND DISCUSSIONS}

\section{A. Employees profile (Staff)}

- Majority $(86.7 \%)$ of the respondents are male and $13.3 \%$ of the respondents are female.

- Majority (half) of the respondents have a place with the age bunch 31-35 yrs.

- Most (46.7\%) the respondents are Under Graduates, $26.7 \%$ of the respondents are Post Graduates and Diploma Holders. [8], [10],[12]

- Most (43.3\%) of representatives are 5-10 yrs of experience, $33.3 \%$ of respondents are knowledgeable about $11-15$ yrs and $16.7 \%$ of workers are experienced over 15 yrs.

- Majority (60\%) of worker have 3-5 family wards, $36.7 \%$ of representatives have below3 wards. [13], [15],[17]

\section{B. Satisfaction level of Staff}

- Majority (60\%) of the respondents were concurred with open to working hours, $40 \%$ of the respondents were concurred and not ready to choose about the exorbitant remaining burden. Lion's share $(80 \%)$ of the respondents were concurred that sufficient offices given by the association and greater part $(53 \%)$ of respondents were happy with the contamination free workplace. [14], [16],[18]

- Majority (63.3\%) of the respondents were happy with simple way to deal with their supervisor, larger part (53.3\%) of the respondents were concurred that their unrivaled value their exhibition, lion's share $(60 \%)$ of the respondents were concurred that their bosses treating appropriately and dominant part (56.7\%) of respondents were happy with the regarding the conclusion and proposals.

- Majority (63.3\%) of respondents were happy with 
the cheerful workplace and $73.3 \%$ of respondents concurred that their partners are useful.

- Majority $(60 \%)$ of respondents concurred that their presentation are perceived, $70 \%$ of the respondents fulfilled for perceiving their exhibition by advancement, $56.7 \%$ respondents fulfilled for perceiving their exhibition by augmentation and half of respondents were happy with advancement approaches.

- $40 \%$ of the respondents concurred that their pay similar to their endeavors and $36.7 \%$ of respondents were expecting an adjustment in present pay scale.

- Majority (53.3\%) of respondents were happy with the flask offices and transport offices, $66.7 \%$ of respondents were happy with the wellbeing arrangements and credits given by the association and $60 \%$ of respondents were happy with therapeutic offices. [19], [21],[23]

- Majority (63.3\%) of respondents were content with the organization approaches and $76.3 \%$ of respondents were concurred that professional stability depends on execution.

- Majority $(70 \%)$ of the respondents were happy with the complaint dealing with system and $60 \%$ of respondents had the option to openly impart their complaint.

- Majority (66.7\%) of the respondents were happy with the basic of execution examination, half of respondents concurred their presentation evaluation kept classified and $66.7 \%$ of respondents concur that exhibition evaluation improves their presentation.

- Majority $(70 \%)$ of the respondents were concurred that they gave sufficient T/D program, $76.7 \%$ of respondents concurred that preparation program is useful.

- Majority (76.7\%) respondents were happy with the line of the board, $73.3 \%$ of respondents happy with the basic leadership gauges and $63.3 \%$ of respondents concurred that their thoughts were given significance in basic leadership.

- Majority $(70 \%)$ respondents knew about quality measures, $66.7 \%$ of respondents happy with the ISO testament and $70 \%$ of respondents concurred that wide prospects due to ISO accreditation.

- Majority (46.7\%) respondents knew about advising program, $63.3 \%$ of respondents happy with the vocation guiding and $66.7 \%$ of respondents concurred that profession directing aides in profession arranging.

- $60 \%$ of the respondents are happy with the satisfactory open door given by association to develop, $66.7 \%$ of the respondents are happy with the plentiful chances and given extra obligation and $40 \%$ of the respondents are happy with the inward advancements.

- Majority (73.3\%) of the respondents are fulfilled about the expected set of responsibilities and individual objectives in the association, $66.7 \%$ of the respondents are happy with their commitment towards their objective and $53.5 \%$ of the respondents are happy with their offered specialist to satisfy their obligation. [20], [22], [24]

- $63.3 \%$ of the respondents are fulfilled that they show signs of improvement status in the general public and pleased to work in the association, $46.7 \%$ respondents are exceptionally happy with the great name of the organization's item, the generosity of the association and altruism of the association.

\section{Factors influencing satisfaction of staff}

Factors influencing are satisfaction in

- Comfortable working hours, simple way to deal with manager

- Cordial association with the partners, perceiving the exhibition

- Salary equivalent with the endeavors, credits gave

- Company arrangements, complaint dealing with system [25], [27], [29]

- Essential execution examination, preparing helps in expanding execution

- Decision making models, mindful of value approach

- Career directing aides in vocation arranging

- Job intriguing and imminent, given satisfactory chance to perform, development of the association.

\section{CONCLUSION}

This part manages the exchanges on the discoveries and the proposed suggestions dependent on the discoveries. [26], [28], [30]

The main considerations which aides in structure the worker connection in the working climate are Satisfy the necessities of the clients, Manager illuminates the proposed changes, Loyalty,Management and representative relationship is genial, Proud to be in this association, Employee are dealt with decently, Retain the clients, Encouraged to build up the abilities set of the workers and Decision taking specialist [31], [33]. It very well may be gathered that the significant occasions are collaborators, clients, chiefs, supervisor and executive. The workers have the best association with the chief

\section{REFERENCES}

1) BharthVajan R., Ramachandran S.,Psychographic dimensions of training,2016,International Journal of Pharmacy and Technology,V-8,I-4,P-23727-23729

2) Balakrishnan P., Bharthvajan R.,A study on human resource planning in hospitals in Chennai City,2014,International Journal of Applied Engineering Research,V-9,I-22,P-7503-7507

3) Priyadarsini P., Bharthvajan R.,Role of emotional intelligence training programme in reducing the stress of the nurses,2014,International Journal of Applied Engineering Research,V-9,I-22,P-7411-7421

4) Kerinab Beenu G., Bharthvajan R.,Empirical analysis on the cosmetic buying behavior of young women in South India,2014,International Journal of Applied Engineering Research,V-9,I-22,P-7361-7366

5) Balakrishnan P., Bharthvajan R.,Whistling in the wind,2014,International Journal of Applied Engineering Research,V-9,I-22,P-7586-7593

6) Krishnan B., Peter M.,Health hazards of Indian Bpo employee-an alarming issue,2014,International Journal of 
Applied Engineering Research,V-9,I-22,P-7336-7341

7) Kerinab Beenu G.H., Peter M.,Role of insurance in economic development,2014,International Journal of Applied Engineering Research,V-9,I-22,P-7532-7539

8) Balakrishnan P., Peter M., Priyadarsini P.,Efficiency of safety measures for wellbeing of employees in manufacturing industry,2014,International Journal of Applied Engineering Research,V-9,I-22,P-7376-7382

9) Anbarasi M., Praveen Kumar S.,Online sales promotions of herbal products and its effectiveness towards tanisha.com,2019,Indian Journal of Public Health Research and Development,V-10,I-1,P-195-200

10) Anbarasi M., Praveen Kumar S.,Various online marketing and promotions strategies to improve the validation towards the organic products in the pharmaceutical sectors, 2019, Indian Journal of Public Health Research and Development,V-10,I-1,P-263-269

11) Loganathan R., Praveen Kumar S.,Grievance handling a key factor for solving issues of employees in an organization,2014,International Journal of Applied Engineering Research,V-9,I-22,P-7483-7491

12) Loganathan R., Praveen Kumar S.,Study on preference of private label brands in super and Hypermarkets,2014,International Journal of Applied Engineering Research,V-9,I-22,P-7327-7335

13) Smitha M., Praveen Kumar S.,Understanding stress and its managementamong the nurses in Chennai city,2014,International Journal of Applied Engineering Research,V-9,I-22,P-7560-7565

14) Kerinab Beenu G.H., Praveen Kumar S.,A study on the investment behavior of Chennai investors in mutual fund schemes,2014,International Journal of Applied Engineering Research,V-9,I-22,P-7520-7525

15) Loganathan R., Praveen Kumar S.,Retention strategies key for organizational productivity,2014,International Journal of Applied Engineering Research,V-9,I-22,P-7443-7447

16) Pavithra J., Ganesan M., Brindha G.,State wise analysis of microfinance sector in India,2016,International Journal of Pharmacy and Technology,V-8,I-4,P-23417-23432

17) Pavithra J., Ganesan M.,A comparative study on microfinance in India and abroad,2016,International Journal of Applied Business and Economic Research,V-14,I-8,P-5471-5476

18) Pavithra J., Ganesan M.,A study on awareness and impact of micro-financial schemes,2016,International Journal of Applied Business and Economic Research,V-14,I-8,P-5449-5460

19) Senthilmurugan P., Pavithra J.,Consumer preference towards organised retailing with reference to Big Bazaar,2014,International Journal of Applied Engineering Research,V-9,I-22,P-7469-7475

20) Senthilmurugan P., Pavithra J.,Implication of social media marketing in growing healthcare industry,2014,International Journal of Applied Engineering Research,V-9,I-22,P-7448-7456

21) Loganathan R., Pavithra J.,Consumer perception towards private label brand over other brands in super markets and hypermarkets,2014,International Journal of Applied Engineering Research,V-9,I-22,P-7355-7360

22) Kerinab Beenu G., Pavithra J.,Tradeâ€"off between liquidity and profitability in logistics industry,2014,International Journal of Applied Engineering Research,V-9,I-22,P-7398-7401

23) Kerinab Beenu G., Pavithra J.,A study on the prospective consumerâ $€^{\mathbf{T M}_{S}}$ perception towards utility cars in Chennai city,2014,International Journal of Applied Engineering Research,V-9,I-22,P-7526-7531

24) Pavithra J., Dilli Babu P., Ambuli T.V.,A study on budgetary control at Maruti Service Masters, Chennai,2014,International Journal of Applied Business and Economic Research,V-12,I-2,P-151-161

25) Pavithra J., Dilli Babu P., Ambuli T.V.,A study on customer satisfaction of retro Garments Pvt Ltd, Chennai,2014,International Journal of Applied Business and Economic Research,V-12,I-2,P-381-391

26) Kerinab Beenu G.H., Pavithra J., Senthilmurugan P.,A study on the influence of promotional activities for TATA ARIA among consumers in Chennai,2014,International Journal of Applied Engineering Research,V-9,I-22,P-7572-7578

27) Vijayaragavan S.P.,An investigative expert that's general FBG sensors,International Journal of Mechanical Engineering and Technology,V-8,I-8,PP-1500-1505,Y-2017

28) Vijayaragavan S.P.,Equalization routing protocol for Wi-Fi sensor strategy,International Journal of Mechanical Engineering and Technology,V-8,I-8,PP-1662-1666,Y-2017

29) Karthik B., Kiran Kumar T.V.U., Vijayaragavan P., Bharath Kumaran E.,Design of a digital PLL using 0.35 $\hat{\mathrm{I}}^{1 / 4 \mathrm{~m}}$ CMOS technology,Middle East Journal of Scientific Research,V-18,I-12,PP-1803-1806,Y-2013

30) Kanniga E., Selvaramarathnam K., Sundararajan M.,Kandigital bike operating system,Middle - East Journal of Scientific Research,V

31) Jasmin M., Vigneshwaran T., Beulah Hemalatha S.,Design of power aware on chip embedded memory based FSM encoding in FPGA,International Journal of Applied Engineering Research,V-10,I-2,PP-4487-4496,Y-2015

32) Jasmin M.,Optimization techniques for low power VLSI circuits,Middle East Journal of Scientific Research,V-20,I-9,PP-1082-1087,Y-2014
33) Jasmin M., Vigneswaran T.,Fuzzy controller for error control of on - Chip communication,2017 International Conference on Algorithms, Methodology, Models and Applications in Emerging Technologies, ICAMMAET 2017,V-2017-January,I-,PP-1-5,Y-2017

\section{AUTHORS PROFILE}

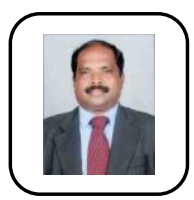

Mr. R. Ramamoorthy Assistant Professor, Department of MBA, Bharath Institute of Higher Education and Research, Chennai, India.

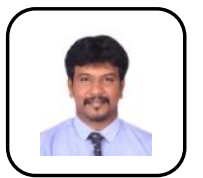

Venkat Raman S Assistant Professor, Department of Civil Engineering, Bharath Institute of Higher Education and Research, Chennai, India.

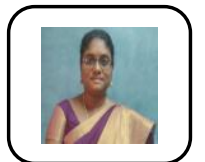

Anitha - K Assistant Professor, Department of Civil Engineering, Bharath Institute of Higher Education and Research, Chennai, India. 